\title{
„Wolność pracy, przedsiębiorczość i uczestnictwo” jako alternatywa dla socjalizmu i kapitalizmu
}

Czas związany z ogłoszeniem trzeciej i ostatniej encykliki społecznej św. Jana Pawła II, stanowiącej zwieńczenie jego nauczania społecznego, był czasem znamiennym ${ }^{1}$. $\mathrm{Z}$ jednej strony minęło dokładnie sto lat od ogłoszenia encykliki Rerum novarum, dokumentu konstytuującego nową dziedzinę w refleksji moralnej Kościoła, czyli katolicką naukę społeczną. Z drugiej strony przełomowe wydarzenia roku 1989 odbiły swoje nieusuwalne piętno na dokumencie społecznym wprowadzającym nauczanie społeczne Kościoła w nowe millenium, jakim stała się niewątpliwie encyklika Centesimus annus.

Z dzisiejszej perspektywy niektóre, pisane wtedy na gorąco, oceny i komentarze dotyczące dzieła św. Jana Pawła II wydają się aż nazbyt uproszczone. Można stwierdzić, że tamte reakcje niosą na sobie ślady modnych w epoce przełomu tendencji. Dotyczy to głównie głosów dobiegających ze środowisk liberalno-konserwatywnych. Żywo dyskutowanym problemem stała się wtedy kwestia: „Czy Kościół zaakceptował kapitalizm, czy też nie?”. Tak postawiony problem stał się przyczyną wielu ostrych polemik.

Tamtejsze oceny, podyktowane tzw. ,ideologią wolnorynkową", wydają się dziś anachronizmem w perspektywie wydarzeń i zjawisk, jakie pojawiły się już po ogłoszeniu Centesimus annus, które związane były i są z intensyfikacją procesów globalizacyjnych. Uproszczona publicystyczno-medialna interpretacja słynnego eseju Francisa Fukuyamy Koniec

1 Por. M. Zięba, Jestem z wami. Kompendium twórczości i nauczania Karola Wojtyły Jana Pawła II, Kraków 2010, s. 95. 
historii $i^{2}$ oraz hasło Margaret Thatcher, że "nie ma żadnej alternatywy” (TINA) ${ }^{3}$ wobec wolnego rynku i demokracji liberalnej, z dzisiejszej perspektywy brzmią wręcz naiwnie. Wszystkie fale kryzysu ekonomicznego, jaki rozpoczął się jesienią 2008 roku, drastyczne pogłębienie się różnic społecznych w świecie (nie tylko trzecim), wolny przepływ kapitału owocujący finansjalizacją gospodarki, ucieczka przemysłu do krajów o niskich kosztach pracy oraz kryzys emigracyjny spowodowały swoistą koniunkturę na poszukiwanie nowych rozwiązań w zakresie systemów społeczno-gospodarczych. Niektórzy zaczęli mówić wręcz o zmierzchu kapitalizmu ${ }^{4}$, otwierając pole do kreślenia nowych modeli ustrojowych, nierzadko o charakterze utopijnym.

Temat zadany przez redaktorów niniejszego zbioru, zatytułowany: " «Wolność pracy, przedsiębiorczość i uczestnictwo» jako alternatywa dla socjalizmu i kapitalizmu", siłą rzeczy wpisuje się w refleksję nad poszukiwaniem alternatyw wobec systemu, który z pozoru nie powinien mieć już żadnych alternatyw. Tytuł niniejszego tekstu nawiązuje do ważnego stwierdzenia zawartego w Centesimus annus, które odnosi się do poszukiwań alternatywy wobec systemu kapitalistycznego opartego na absolutnej dominacji kapitału. Papież pisze, że „w walce z tym systemem modelem alternatywnym nie jest system socjalistyczny, który w rzeczywistości okazuje się kapitalizmem państwowym, lecz społeczeństwo, w którym istnieją: wolność pracy, przedsiębiorczość i uczestnictwo. Tego rodzaju społeczeństwo nie przeciwstawia się wolnemu rynkowi, ale domaga się, by poprzez odpowiednią kontrolę ze strony sił społecznych i państwa było zagwarantowane zaspokojenie podstawowych potrzeb całego społeczeństwa"s.

Powyższe stwierdzenie zainspirowało nieżyjącego już dziś ks. prof. Franciszka Jana Mazurka do zatytułowania w ten właśnie sposób publikacji z 1993 roku$^{6}$. Autor dał się poznać jako obrońca (oraz kreatywny twórca) koncepcji systemu gospodarczego, w centrum którego ma stać człowiek wyposażony przez Stwórcę w swą niezbywalną godność. Sys-

\footnotetext{
Por. F. Fukuyama, Koniec historii, tłum. T. Bieroń, M. Wichrowski, Kraków 2009.

Akronim od ang. There is no alternative.

Por. J. Żakowski, Zawat. Zrozumieć kryzys, Warszawa 2009, s. 8.

Por. CA 35.

6 F. J. Mazurek, Wolność pracy, przedsiębiorczość i uczestnictwo, Lublin 1993.
} 
tem gospodarczy ma służyć człowiekowi, który podejmując działalność przedsiębiorczą, ma tym samym afirmować swoją wolność. Mazurek podjął ostrą polemikę z tzw. „katolickimi liberałami” głoszącymi, że Jan Paweł II w encyklice Centesimus annus „zaakceptował” kapitalizm w takiej postaci, w jakiej istnieje on obecnie. Lubelski twórca katolickiej nauki społecznej opowiadał się za prawdziwym kapitalizmem, w którym nastąpiłoby realne upowszechnienie własności, w przeciwieństwie do istniejącego systemu, w którym własność jest domeną jedynie wąskiej grupy ludzi bogatych i uprzywilejowanych?

Porządek metodologiczny domaga się najpierw wyjaśnienia i dopracowania, co oznaczać mogą poszczególne hasła zawarte w tytule niniejszego artykułu, aby następnie dokonać refleksji, na ile owe pożądane hasła „wolności pracy”, „przedsiębiorczości” oraz „uczestnictwa” mogą stanowić alternatywę dla socjalizmu i kapitalizmu. Wspomniana poprawność metodologiczna domagałaby się jeszcze lepszej konceptualizacji pozornie oczywistych pojęć, takich jak „kapitalizm” i „socjalizm”. Stanie się to podstawą do refleksji, czy faktycznie na tej podstawie można mówić o rzeczywistej alternatywie systemowej.

\section{Kapitalizm i socjalizm jedno mają imię}

W encyklice Centesimus annus św. Jan Paweł II obawia się prostego zastosowania pojęcia kapitalizm. Proponuje zamiast niego użycie pojęcia „ekonomia przedsiębiorczości” czy „ekonomia rynku”, czy też „wolna ekonomia"8. Ta obawa świadczy o silnym ładunku ideologicznym tkwiącym w samym pojęciu kapitalizmu. Jest ono synonimem systemu gospodarczo-politycznego opartego na wolnym rynku. Nie jest to pojęcie zbyt ostre, gdyż wolny rynek istnieje zarówno w państwach wysoko rozwiniętych, takich jak Szwajcaria, jak i w krajach rozwijających się, takich jak np. Nigeria. A zatem istnienie rozwiązań wolnorynkowych nie gwarantuje samo z siebie dobrobytu mieszkańców.

Święty Jan Paweł II w encyklice Centesimus annus wyraźnie ukazuje relatywizm powstania historycznych modeli ustrojowych, a mianowicie

7 Por. F. J. Mazurek, Wartości gospodarcze w doktrynie społecznej Kościoła katolickiego, w: Religia a gospodarka, t. 1, red. S. Partycki, Lublin 2005, s. 42-47.

8 Por. CA 42. 
socjalizmu i kapitalizmu, stwierdzając, że: „Kościół nie proponuje żadnych modeli. Realne i naprawdę skuteczne modele mogą zrodzić się jedynie w ramach różnych historycznych sytuacji, dzięki wysiłkowi tych wszystkich, którzy w sposób odpowiedzialny podejmują konkretne problemy we wszystkich ich aspektach społecznych, gospodarczych, politycznych i kulturalnych zazębiających się ze sobą"”. Oznacza to, iż realnie istniejące $\mathrm{w}$ historii modele ustrojowe, czyli kolektywistyczny $\mathrm{i}$ indywidualistyczny, są w znacznym stopniu „dziećmi swojej epoki”, a co za tym idzie - gdyby warunki geopolityczne lub środowiskowe były inne, to mogłyby zrodzić się zupełnie inne modele ustrojowe. Warunki, jakie nastały po opublikowaniu Rerum novarum, zainspirowały wielu myślicieli katolickich do konstruowania własnych alternatywnych koncepcji, takich jak dystrybucjonizm (Hilarie Bellow, Gilbert Keith Chesterton) czy też solidaryzm (Heinrich Pesch). Katolicką naukę społeczną zaczęto określać wówczas mianem "trzeciej drogi” między socjalizmem a kapitalizmem. Jak zauważa Jan Mazur, w pewnym sensie można się z tym zgodzić, jednak nieporozumieniem byłoby traktowanie nauczania społecznego Kościoła jako próby sformułowania określonego nowego modelu społeczno-gospodarczego. Uzasadnienie tej tezy wspomniany autor znajduje w ukazaniu wspólnego pochodzenia, zarówno socjalizmu, jak i kapitalizmu - w oświeceniowym racjonalizmie ${ }^{10}$. A racjonalizm ten diametralnie różni się od, stanowiącego podstawę nauczania społecznego Kościoła, realizmu arystotesowsko-tomistycznego. Racjonalizm oświeceniowy ma charakter "metodyczny”, który zbyt często myli idee z rzeczywistością, stąd też tak łatwo we współczesności wcielać idee w życie, zwłaszcza jeśli wierzy się w to, że ich wcielenie zbuduje nowy wspaniały świat, bez biedy, wojen i konfliktów. Dlatego właśnie Kościół w swoim nauczaniu społecznym stara się raczej głosić konkretne zasady moralne wypływające z prawdy o człowieku, niż zajmować się modelami społecznymi, które ze swej natury i tak są abstrakcyjne.

\footnotetext{
9 Por. CA 43.

${ }^{10}$ J. Mazur, Katolicka nauka społeczna (skrypt dla studentów teologii), Kraków 1992, s. 207.
} 


\section{Cechy alternatywnego systemu: wolność pracy, przedsiębiorczość i uczestnictwo}

Zadany przez autorów niniejszego zbioru problem „wolności pracy” nastręcza nieco trudności. Zagadnienie samej „wolności pracy” nie jest zbyt popularne wśród autorów zajmujących się katolicką nauką społeczną. Znacznie częściej można przeczytać o osobowym wymiarze pracy czy o pierwszeństwie pracy nad kapitałem. Wypada się zatem zastanowić, co oznacza ów postulat „wolności pracy”. Naturalnym jego przeciwieństwem wydaje się praca przymusowa czy też niewolnicza. Nie chodzi jednak w tym miejscu o historyczne niewolnictwo, ale o współczesny przymus pracy związany ściśle z wyzyskiem. Nestor polskiej katolickiej nauki społecznej Czesław Strzeszewski uważa, że „praca jest to wolna, choć naturalnie konieczna działalność człowieka wypływająca z poczucia obowiązku, połączona $\mathrm{z}$ trudem i radością, a mająca na celu tworzenie użytecznych społecznie wartości duchowych i materialnych"11. A zatem „wolność pracy” oznacza, iż człowiek wolny nie jest w swej działalności gospodarczej zdeterminowany dobrami gospodarczymi, czyli jej przedmiotami. Przewaga czynnika przedmiotowego nad ludzkim w życiu gospodarczym oznaczałaby poddanie działalności gospodarczej człowieka mechanicznym prawom rozwoju techniki czy ślepemu cyklowi koniunkturalnemu.

Elementem systemu alternatywnego, ściśle związanym z tak pojętą „wolnością pracy”, jest „przedsiębiorczość”. Rozumie się ją najogólniej jako przejawianie inicjatywy do realizacji działań ludzkich w dziedzinie gospodarczej. Przedsiębiorczość istnieje, od kiedy istnieje człowiek. Gospodarowanie od początku cywilizacji było związane z przedsiębiorczością i przedsiębiorcami. W każdej epoce historycznej miała ona jednak inne konotacje, gdyż nie każda gospodarka oraz nie każdy system społeczno-polityczny stwarza warunki sprzyjające rozwojowi przedsiębiorczości ${ }^{12}$. Poglądy mówiące, że to przedsiębiorczość jest główną siłą napędową gospodarki i jej podstawowym „motorem postępu" oraz akceleratorem rozwoju gospodarczego, upowszechnił dopiero

\footnotetext{
${ }_{11}$ Por. C. Strzeszewski, Katolicka nauka społeczna, Lublin 1994, s. 580.

${ }_{12}$ Co ciekawe, klasyczna ekonomia liberalna nie dostrzegała roli indywidualnej przedsiębiorczości w systemie gospodarczym, podobnie jak ekonomia marksistowska.
} 
Joseph A. Schumpeter. Jego zdaniem podstawową funkcją przedsiębiorcy jest reformowanie lub rewolucjonizowanie stosowanego do tej pory wzorca produkcji, wprowadzanie i wykorzystywanie nowych pomysłów, nierozpoznanej technicznej możliwości nowego lub znanego towaru za pomocą nowych metod. Według Schumpetera przedsiębiorca nie jest wynalazcą, gdyż wynalazca dostarcza idei, a przedsiębiorca podejmuje czyny, umie odpowiednio wykorzystać rezultaty twórczej działalności wynalazcy ${ }^{13}$.

Mimo iż pojęcie przedsiębiorczości upowszechnił Schumpeter, to samo pojęcie "przedsiębiorca” (entrepreneur), pochodzące z języka francuskiego, zostało użyte w 1755 roku przez Richarda Cantillona, francuskiego ekonomistę zajmującego się biznesem i finansami. Jako pierwszy nadał on temu pojęciu sens techniczny, przypisując przedsiębiorcy centralną rolę w handlu. Oznacza to, że przedsiębiorczość w dzisiejszym znaczeniu wywodzi się z początków rewolucji przemysłowej, której wstępną fazą był kapitalizm manufakturowy. Wtedy narodziły się pierwsze działania przedsiębiorcze. W tym okresie przedsiębiorca był utożsamiany z kupcem. Jego działalność wyrażała się w nowej, jak na owe czasy - rewolucyjnej, filozofii gospodarowania. Jej celem było osiąganie zysków, wyzwalanie ludzkich ambicji oraz stwarzanie ich możliwości w praktyce. Postawa taka nie była łatwa do zaakceptowania przez społeczeństwo, napotykała na opór społeczny i napiętnowanie. Niemniej jednak to kapitalizm zlikwidował feudalne bariery uniemożliwiające rozwój przedsiębiorczości, stworzył odpowiednie warunki do jej rozwoju: polityczno-gospodarczą wolność, prywatną własność środków produkcji, rynek wraz z funkcjonującą na nim konkurencją. To właśnie te uwarunkowania uważa się za bazowe założenia gospodarki rynkowej, ułatwiające podejmowanie i prowadzenie działalności gospodarczej ${ }^{14}$.

Wspomniany Schumpeter utożsamił kapitalistyczną przedsiębiorczość z realizacją procesu „twórczej” destrukcji. Oznacza on powstawanie "nowych kombinacji” środków produkcji umożliwiających wprowadzenie nowego wyrobu bądź technologii czy też otwarcie nowego rynku zbytu, pozyskanie nowych źródeł zasobów lub nowej formy organizacji

${ }_{13}$ Por. T. Piecuch, Przedsiębiorczość. Podstawy teoretyczne, Warszawa 2010, s. 14-15.

${ }^{14}$ Por. tamże, s. 16. 
produkcji ${ }^{15}$. Kontynuatorem myśli Schumpetera był Peter F. Drucker, który owym innowacjom przypisał podstawową rolę $\mathrm{w}$ działalności przedsiębiorczej. Według Druckera to innowacje nadają z pozoru bezproduktywnym zasobom nowe możliwości tworzenia bogactwa. Uznał on, że innowacja to praca wymagająca wiedzy i pomysłowości oraz odpowiednich predyspozycji. Sama innowacja jest skutkiem procesów zachodzących w gospodarce i społeczeństwie, czyli zmianą w zachowaniach ludzi, w tym, jak pracują, czy produkują cokolwiek. Innowacja jest, według Druckera, podstawową funkcją przedsiębiorczości, przenika wszystkie fazy biznesu. Może przejawiać się w produkcie, projekcie, technice, marketingu. Może też znaleźć miejsce w usługach, w organizacji lub metodach zarządzania. Drucker dużo miejsca w swoich rozważaniach poświęcił roli menedżerów we współczesnej gospodarce. Wprowadził rozróżnienie na kapitalistę, właściciela i menedżera. Zdaniem amerykańskiego ekonomisty bez przywództwa menedżerów środki produkcji pozostaną jedynie środkami i nigdy nie staną się samą produkcją ${ }^{16}$.

Ekonomiczna teoria przedsiębiorczości uległa w dzisiejszych czasach dalszej ewolucji. O ile pierwotnie koncentrowano się na przedsiębiorczości indywidualnej pojedynczych osób, to w latach 70. xx wieku zaczęto doceniać przedsiębiorczość małych i średnich firm, zdolnych do konkurencji w dziedzinie innowacji z wielkimi międzynarodowymi korporacjami. Obecnie większą wagę przykłada się do przedsiębiorczości i innowacyjności dużych przedsiębiorstw. Chodzi tu o tzw. intraprzedsiębiorczość, w czym wiodą prym firmy dalekowschodnie, np. Samsung. Ostatnią cechą alternatywnego systemu jest „uczestnictwo”. Odrodzenie po 1989 roku zainteresowania ideą społeczeństwa obywatelskiego spowodowało, że koncepcja ta stała się normą i zarazem wzorem dla społeczeństw postkomunistycznych przechodzących proces transformacji z modelu centralistycznego w pluralistyczny. Szczytu dążeń do realizacji obywatelskości społecznej należy upatrywać w tzw. demokracji

15 Por. T. Piecuch, Przedsiębiorczość. Podstawy teoretyczne, s. 23. Schumpeter określił przedsiębiorcę jako „kreatywnego niszczyciela” tworzącego przez unicestwianie. Tym samym uprawia „techniczny lub produkcyjny kanibalizm”, polegający na zastępowaniu jeszcze sprawnych maszyn, produktów i usług innymi, bardziej sprawnymi, często działającymi na innej zasadzie. Proces ten jest oparty na innowacjach niszczących dawne sposoby eksploatacji - poprzez tworzenie nowych, doskonalszych.

${ }^{16}$ Por. tamże, s. 30-31. 
partycypacyjnej. Chodzi o stworzenie takiego modelu regulacji stosunków społecznych, w którym podstawowe instytucje życia publicznego są kształtowane przez ogół obywateli. Katolicka nauka społeczna, doceniając dążenia do autentycznej partycypacji społecznej, kładzie nacisk na uczestnictwo pracujących w zarządzaniu przedsiębiorstwem. A zatem pojęcie partycypacji społecznej zostaje rozciągnięte na płaszczyznę gospodarczą ${ }^{17}$.

Jednym z czołowych myślicieli współczesności odwołujących się do idei partycypacji jest Jürgen Habermas. Idea społeczeństwa obywatelskiego stanowi rdzeń jego koncepcji teoretycznej. Według niemieckiego filozofa społecznego obecnie w naukach społecznych można wyróżnić dwa podstawowe modele aktywnego obywatelstwa. Chodzi o model liberalny oraz o model republikański. Pierwszy, liberalny, wywodzący się od Johna Locke'a, wyróżnia się indywidualistycznym oraz instrumentalnym rozumieniem roli obywatela. Głównym założeniem tej idei jest uznanie, że jednostki funkcjonują na zewnątrz państwa i mają wobec niego zobowiązania (udział w wyborach, płacenie podatków) oraz oczekiwania (np. świadczenia socjalne). W tym ujęciu obywatele nie odróżniają się specjalnie od osób prywatnych, którzy swoje osobiste interesy przeciwstawiają aparatowi państwa ${ }^{18}$.

Drugi model, republikański, wywodzący się od Arystotelesa oraz częściowo od Thomasa Hobbesa, został (według Habermasa) oparty na komunitarnym i etycznym rozumieniu roli obywatela, jego przynależności do pewnej samookreślającej się wspólnoty etyczno-kulturalnej. Członkowie wspólnoty politycznej są z nią zintegrowani na tyle, że ich tożsamość osobowa i społeczna może się wykształcić tylko przy wykorzystaniu wspólnej tradycji, akceptowalnych instytucjach politycznych, a obywatelstwo wyraża się w takim modelu poprzez działania kolektywne, urzeczywistnianie wspólnoty etycznej, zinstytucjonalizowanej zgodnie $\mathrm{z}$ interesem państwa ${ }^{19}$.

${ }_{17}$ Por. S. Fel, Praca - kapitat - demokracja. Konsekwencje praktyczne zasady pierwszeństwa pracy nad kapitałem, Lublin-Stalowa Wola 2003, s. 126.

${ }_{18}$ Por. P. Weryński, Polskie wzory uczestnictwa w sferze publicznej. Próba typologizacji postaw, w: Społeczeństwo obywatelskie między idea a praktyką, red. A. Kościański, W. Misztal, Warszawa 2008, s. 137.

${ }_{19}$ Por. tamże. 
Powyższe dwie koncepcje realizacji idei społeczeństwa obywatelskiego klasyfikowane przez Habermasa stanowią jedynie przyczynek do szerokiej debaty nad wieloaspektowością tej idei oraz różnymi jej odmianami. Pojęcie partycypacji społecznej jest bardzo szerokie, gdyż stanowi ono domenę idei konserwatywnych przeciwstawiających się omnipotencji instytucji państwowych, a także inspirację dla koncepcji lewicowych będących współczesnymi utopiami, których w ostatnim czasie powstało bardzo wiele (np. David C. Korten).

Idee partycypacji w dziedzinie gospodarczej można odnaleźć już u Alexisa de Tocqeville'a. Chodzi w tym przypadku o stworzenie autentycznej demokracji obejmującej także sferę gospodarczą, która stała się swoistą oligarchią ludzi bogatych oraz polem dominacji autonomicznych rynków finansowych. W przypadku tych negatywnych zjawisk problemem staje się bierność ludzi pracujących, traktowanych jako jedynie bierna siła robocza. Oznacza to, że pełne włączenie pracobiorców w proces życia gospodarczego jest ważnym zadaniem polityki społecznej i gospodarczej. Pracobiorca, podobnie jak obywatel, pragnie dzisiaj być nie tylko przedmiotem cudzych decyzji, ale jego aspiracje idą w kierunku partnerskiego współdziałania i współdecydowania. W odpowiedzi na te dążenia doktryna społeczna Kościoła już w latach 30. xx wieku sformułowała postulat dopuszczenia pracowników do udziału w zyskach, we własności i w zarządzaniu przedsiębiorstwem ${ }^{20}$.

\section{Poszukiwanie rzeczywistej alternatywy ustrojowej}

Ukazane powyżej zawiłości pozwalają jednoznacznie stwierdzić, że zarówno wolność pracy, przedsiębiorczość oraz uczestnictwo nie stanowią i nie mogą stanowić jakiejś odrębnej koncepcji ustrojowej. Czy zatem mogą być alternatywą wobec socjalizmu i kapitalizmu? Jeśli chodzi o system tzw. „realnego socjalizmu”, czyli takiego, jaki istniał w krajach RW PG przed 1989 rokiem, to zdecydowanie tak, gdyż żaden z tych postulatów nie był w pełni respektowany przez system nakazowo-rozdzielczy. Oczywiście nie ma realnie istniejących systemów stanowiących weberowskie typy idealne. W realnym socjalizmie istniały przestrzenie wolnorynkowe,

\footnotetext{
${ }^{20}$ Por. S. Fel, J. Kupny, Humanizacja życia gospodarczego. Wybrane zagadnienia z etyki gospodarczej, Lublin 200o, s. 115.
} 
zaś najbardziej radykalny system kapitalistyczny spełnia funkcje socjalne i nie jest czystym darwinizmem społecznym. W encyklice Centesimus annus wolność pracy, przedsiębiorczość i uczestnictwo są postulatami, które mają być respektowane w dobrze funkcjonującej gospodarce wolnorynkowej. Stąd też w tym rozumieniu mogą stanowić alternatywę wobec obecnego kształtu „sfinansjalizowanego" oraz „zglobalizowanego” systemu kapitalistycznego ${ }^{21}$. Po II wojnie światowej w RFN rozwinął się system społecznej gospodarki rynkowej (SGR) utożsamiany z ordoliberalizmem. Model ten, stanowiący podstawę integracji europejskiej, niewątpliwie przeżywa dziś swój wieloaspektowy kryzys. Model SGR mógł funkcjonować na etapie powojennej odbudowy gospodarki niemieckiej $\mathrm{w}$ ramach gospodarki narodowej ${ }^{22}$. Taki system miał gwarantować wolność pracy, przedsiębiorczości i uczestnictwo. Wolność pracy, ściśle związaną z przedsiębiorczością, gwarantowała gospodarka rynkowa, w której arbitrem gry rynkowej było państwo, z kolei uczestnictwo w zarządzaniu przedsiębiorstwem gwarantowały ciała przedstawicielskie i procedury negocjacyjne. Trudno jednak powiedzieć, czy dziś ów system jest realną alternatywą dla świata pogrążonego $\mathrm{w}$ anarchii narzucanej przez rynki finansowe.

Jednak mimo wszystko należy stwierdzić, że kształt globalizacji, jaki został zaaplikowany światu już po napisaniu i ogłoszeniu Centesimus annus, spowodował, iż postulaty wolności pracy, przedsiębiorczości i uczestnictwa są jeszcze bardziej aktualne.

\section{Bibliografia}

Dembinski P. H., Berenta S., Kryzys ekonomiczny i kryzys wartości, tłum. Ł. Komuda, Kraków 2014.

Dylus A., Społeczna gospodarka rynkowa jako podstawa ustroju gospodarczego Polski, w: Ku obywatelskiej rzeczypospolitej gospodarczej, red. W. Gasparski, B. Rok, Warszawa 2010, s. 51-64.

${ }^{21}$ P. H. Dembinski, S. Beretta, Kryzys ekonomiczny i kryzys wartości, tłum. Ł. Komuda, Kraków 2014, s. 19-49.

${ }^{22}$ Por. A. Dylus, Społeczna gospodarka rynkowa jako podstawa ustroju gospodarczego Polski, [w:] Ku obywatelskiej rzeczypospolitej gospodarczej, red. W. Gasparski, B. Rok, Warszawa 2010, s. 51-64. 
Fel S., Kupny J., Humanizacja życia gospodarczego. Wybrane zagadnienia z etyki gospodarczej, Lublin 2000.

Fel S., Praca - kapitat - demokracja. Konsekwencje praktyczne zasady pierwszeństwa pracy nad kapitałem, Lublin-Stalowa Wola 2003.

Fukuyama F., Koniec historii, tłum. T. Bieroń, M. Wichrowski, Kraków 2009.

Jan Paweł II, Encyklika Centesimus annus, przedruk: Libreria Editrice Vaticana, Włocławek 1991.

Leon xiII, Encyklika Rerum novarum, Te Deum, Warszawa 2001.

Mazur J., Katolicka nauka społeczna (skrypt dla studentów teologii), Kraków 1992.

Mazurek F. J., Wartości gospodarcze w doktrynie społecznej Kościoła katolickiego, w: Religia a gospodarka, t. 1, red. S. Partycki, Lublin 2005, s. 42-47.

Mazurek F. J., Wolność pracy, przedsiębiorczość i uczestnictwo, Lublin 1993.

Piecuch T., Przedsiębiorczość. Podstawy teoretyczne, Warszawa 2010.

Strzeszewski Cz., Katolicka nauka społeczna, Lublin 1994.

Weryński P., Polskie wzory uczestnictwa w sferze publicznej. Próba typologizacji postaw, w: Społeczeństwo obywatelskie między idea a praktyką, red. A. Kościański, W. Misztal, Warszawa 2008.

Zięba M., Jestem z wami. Kompendium twórczości i nauczania Karola Wojtyły Jana Pawła II, Kraków 2010.

Żakowski J., Zawat. Zrozumieć kryzys, Warszawa 2009.

\section{Abstrakt}

Artykuł stara się ogarnąć refleksją jeden z ważnych problemów postawionych przez św. Jana Pawła II w encyklice Centesimus annus. Chodzi bowiem o pytanie: czy system społeczno-gospodarczo-polityczny, który gwarantuje jednocześnie wolność pracy, przedsiębiorczość oraz uczestnictwo - stanowi alternatywę dla socjalizmu (realnie istniejącego przed 1989 rokiem) i kapitalizmu (w obecnym kształcie)? Tekst zawiera analizę wyżej wymienionych pojęć z perspektywy lansowanego dziś ideału innowacyjnej gospodarki. Innowacyjność ta oparta jest na ludzkiej wiedzy i kreatywności oraz postulacie budowania społeczeństwa obywatelskiego z uwzględnieniem zasady uczestnictwa. 


\title{
„Freedom of work, entrepreneurship and participation”
} as an alternative to socialism and capitalism

\begin{abstract}
This article seeks to reflect on one of the important issues raised by St. Pope John Paul II in the encyclical Centesimus annus. The issue in question is: is a socio-economic and political system which guarantees freedom of work, enterprise and participation an alternative to socialism (as it actually existed prior to 1989) and capitalism (in its current form)? The text includes an analysis of the above-mentioned concepts from the perspective of an innovative economy, an ideal which is promoted today. This innovation is based on human knowledge and creativity and on the postulate of building a civil society which takes into account the principle of participation.
\end{abstract}

